Article

\title{
Alternative Networks of Globalisation: Latvian Neorealism in the Films of Laila Pakalnina
}




\section{ABSTRACT}

This paper examines the development of neorealist tendencies in the oeuvre of contemporary Latvian filmmaker Laila Pakalnina. Her work is positioned within the global dissemination of cinematic neorealism, and its local manifestations, which, it is argued, develop in specific national contexts in reaction to dramatic societal and political changes. Pakalnina's films are examined as a documentation of the change from a communist satellite state to an independent democratic, capitalist country. Heavily influenced by the Riga School of Poetic Documentary, a movement in Latvian cinema that adhered to the conventions of poetic documentary filmmaking, the article analyses how her films replicate and further develop the stylistic and aesthetic devices of the Italian neorealists and the succeeding cinematic new waves. In doing so the argument is put forth that Pakalnina has developed neorealism Latvian style.

Due to their size, small nations do not possess the economic or political capital to participate in dominant networks of globalisation, which serve the interests of larger, wealthier nations that use global networks for political or financial gain (Hjort, Petrie 2007: 8). Thus, small nations and the filmmakers in small nations are often part of what Arjun Appadurai has called 'grassroots globalisation' or 'globalisation from below' (Appadurai 2000: 3). Grassroots globalisation contests the hierarchical nature of globalisation that benefits only those who can participate in or drive neoliberal capitalist free trade. It develops an understanding or theory of globalisation 'on behalf of the poor'; of social mobilisation and knowledge transfer outside the global processes of the corporate capitalist and nation-state system that benefit the wealthy (Appadurai 2000: 3).

Latvia lacks political and financial capital and so it is not surprising that grassroots globalisation is also occurring in Latvia. More specifically, the Latvian director Laila Pakalnina is participating in an alternative network of cinema globalisation by re-appropriating the stylistic and aesthetic tropes of Italian neorealism, which positions her work as part of a broader global trend in art cinema. This trend is one of 'new waves'. James Tweedie maintains that the new waves, which started to develop in different national cinemas after World War II, engage with, and further develop, the tropes of Italian neorealism. Tweedie contends that starting with the French New Wave, these art cinemas have created what he calls a "cinematic network with a global reach beyond the obvious example of Hollywood and its worldwide distribution system' (Tweedie 2013: 24). It is the grassroots movement of cinematic globalisation.

This paper examines Laila Pakalnina's films and argues that they should be viewed 
as part of this alternative film community. This is due to her development of a neorealist style specific to the Latvian context. Pakalninga uses an alternative global cinema network to disseminate stories of the Latvian experience to audiences outside of the domestic market, through films such as The Shoe (Kurpe, Latvia/Germany/France, 1998) and Pizzas (Picas, Latvia, 2012), which have travelled to numerous international film festivals. Pakalnina employs well-known aesthetics often associated with Italian neorealism and the successive new waves, thereby becoming part of a larger pattern of alternative global filmmaking. However, before acknowledging Pakalnina's work as part of this alternative global cinematic tendency, it is necessary to further formulate what constitutes this grassroots network.

\section{PAKALNINA AND THE}

\section{GRASSROOTS GLOBAL CINEMA}

Numerous scholars, such as Saverio

Giovacchini and Robert Sklar (2012), Hamid Naficy (2012), Laura E. Ruberto and Kristi M. Wilson (2007), have argued that the reappropriation of the stylistics and themes of Italian neorealism constitutes a global style or global network of alternative cinema. Giovacchini and Sklar contend that neorealism has become a 'citizen of the world' owing to its expropriation by different national cinemas (Giovacchini, Sklar 2012: 11). Naficy points out that the conventions of neorealism have become predominant in various national cinemas during periods of social and political turmoil (Naficy 2012: 232). According to Ruberto and Wilson, neorealism provides an aesthetic framework that is an alternative to the Hollywood imports that dominate the exhibition market in most national cinemas. Tweedie claims that the various cinematic new waves, many of which base their stylistics on the conventions of neorealism, should not be viewed as 'isolated events but as a series of interlaced moments' (Tweedie 2013: 3).

The aforementioned scholars agree that neorealism has been absorbed into different national cinemas with varying results (Giovacchini, Sklar 2012). However Giovac- chini and Sklar emphasise a global neorealist style that often evades definition. Nevertheless, a common denominator appears in the publications on cinematic neorealism. This is the grassroots nature of the style in its many manifestations. A brief examination of Italian neorealism, the progenitor of this style, highlights the development of this grassroots quality or characteristic.

Italian neorealism is generally considered to be a post-World War II phenomenon. Its development is attributed to the new generation of filmmakers, such as Vittorio De Sica and Federico Fellini, who were eager to depict reality and reveal unmasked truths. As Lino Micciché asserts neorealism was a shared ethical position for these young Italian directors (Micciché 2002 in Giovacchini, Sklar 2012: 5). They contested the institutionalisation of cinema by Mussolini and the Fascist government in Italy, which used cinema as a propaganda tool during the 1930s and early 1940s (Eades 2012). Instead, De Sica, Fellini and other neorealist directors used cinema to represent the "brutality of war and its consequences' (Eades 2012: 114). As Mira Liehm states it was a 'moral weapon aimed at the artistic conventions of the past' (Liehm 1984 in Učník 2007: 54).

The Italian neorealists reacted against local artistic conventions and commercial Italian films, as well as the glamour of Hollywood (Ruberto, Wilson 2007: 7). Hollywood films were seen as hiding the realities of ravaged post-war Europe and glossing over the uneven socioeconomic development of a newly modernised Italy (Tweedie 2013: 11). In opposition to Hollywood and the conventions of local commercial cinema the Italian neorealists examined the repercussions of World War II and the changing nature of Italian society, with particular focus on the experiences of the underprivileged. Whether reacting against the institutional propaganda of Italian cinema or the glamour of Hollywood films that depicted a reality very different from their own sociopolitical context, their main purpose was to reveal the real and to make people reflect on reality (Učník 2007: 59-60). 
In order to ensure that their audiences engaged with the social problems they depicted in their films the Italian neorealists took inspiration from the poetic realist experiments of the 1930s. As Luca Caminati argues, the popularity of Griersonian narrative documentaries such as Nanook of the North (USA/France, 1922, directed by Robert J. Flaherty) and Tabu: A Story of the South Seas (USA, 1931, F. W. Murnau) were influential in the development of neorealism in Italy after World War II (Caminati 2012: 58). In turn, documentary stylistics came to constitute the Italian neorealist style (Učník 2007: 56). Neorealist directors often employed nonprofessional actors and filmed on location. Furthermore, the plots of their films were often loosely structured, open-ended and focused on portraying 'slice of life scenes', where the director depicted 'contemporary true-to-life subjects' (Sadoul 1966 in Naficy 2012: 226) completing menial and quotidian tasks (Neupert 2007: 60). The protagonists were often members of the working class and used vernacular dialogue (Sadoul 1966 in Naficy 2012: 226). Most importantly the films implied social criticism (ibid.).

New wave cinematic movements such as the French New Wave, Iranian New Wave and Czech New Wave re-appropriate the documentary style of the Italian neorealists for their own grassroots purposes. As Ruberto and Wilson contend, the neorealist style continues to be attractive to new wave directors who seek to respond to the dominant artistic conventions that aim to cloak socio-political issues and present a romanticised image of the world. Neorealism is appealing because it inspires 'politicized, ideological, and aesthetic alternatives to Hollywood narrative tendencies, while simultaneously accomplishing the task of entertaining' (Ruberto, Wilson 2007: 10). Similarly to the Italian neorealists who were inspired by the poetic realism of docufiction from the 1930s, contemporary manifestations of neorealism occur when a director or directors wish to depict reality or confront their audience with social issues, using stylistic and aesthetic techniques that are both entertaining and innovative.

The deployment of neorealism as a protest against the 'artistic conventions of the past' plays out on both local and global levels. Tweedie insists that cinematic new waves should be seen as developing from a need to account for globalisation. Most new wave filmmakers depict and document the changing political, social, cultural and physical landscapes of their nations, which are brought about by increasing global flows of culture and capital (Tweedie 2013: 6). Tweedie elaborates, stating, "[e]ach of these cinemas is discovered by an international film circuit at the same time that a domestic economic revolution signals the society's engagement with an emerging system of global markets' (Tweedie 2013: 18).

This is further explained through a brief examination of the French New Wave. Directors such as François Truffaut and Jean-Luc Godard were committed to documenting Paris as it experienced its 'second massive modernisation' (Tweedie 2013: 18). This involved unprecedented urbanisation and the emergence of an American-style consumer culture obsessed with images and material products (Tweedie 2013: 47). In other words, they used their films to document and to account for the change in French society brought about by globalisation.

Tweedie suggests that the new waves did not and do not merely account for globalisation, but are also part of, or participate in, the creation of globalisation; an alternative globalisation. The new waves, he states, are part of a historical search for a universal cinematic language. When cinema first appeared, critics envisaged it would surpass the problems of literature by creating a global visual language (Tweedie 2013: 9). Tweedie points out that this search for the 'cinematic tower of Babel' was not successful until after World War II when a 'burgeoning art house and film festival circuit developed into one of the major sites for [an] alternative conception of cinematic globalisation' (Tweedie 2013: 10). Lubica Učník expands Tweedie's argument stating 
that the constant re-appropriation of neorealism by various cinematic new waves has formed 'a constant return of the repressed' (Učník 2007: 55). This further supports the idea that the new waves constitute a grassroots cinematic network, where filmmakers can achieve global reach even when they lack the social and economic capital to participate in the mainstream film exhibition networks dominated by Hollywood films.

The French New Wave of the 1950 s and 1960 s first popularised the Italian neorealist documentary aesthetic as an alternative cinematic language to Hollywood. Various scholars have highlighted the similarities between Italian neorealism and the French New Wave, including Tweedie, Caroline Eades and Richard Neupert. The French New Wave, similarly to the Italian neorealists, tried to capture the reality of post-war France. The new wave directors existed in a rapidly changing landscape where, as mentioned earlier, the modernisation of France led to drastic urbanisation and the emergence of an obsessive consumer culture (Tweedie 2013: 47). They focused not so much on narrative, but pursuant to the neorealist tradition, were engrossed with capturing the modernisation of France by concentrating on 'slice of life' scenes and trying to achieve the greatest verisimilitude. They also filmed on location and employed non-professional actors (Tweedie 2013: 26-27).

Tweedie asserts that the 'new waves' are part of a larger alternative network of cinematic globalisation, but that local experience is still very important. The Italian neorealists and French New Wave directors were primarily interested in recording the 'particularities of a unique local experience' (Tweedie 2013: 18), i.e. how post-World War II modernisation was affecting the landscapes and social practices of their nation. While the characteristics of, and motivations behind, the new waves are similar, their content is uniquely different. As Tweedie states, 'particular regions experience their own dynamics of power and resistance' (Tweedie 2013: 8). In a similar vein Ruberto and Wilson argue that neore- alism in its many manifestations is often irreconcilable with Italian neorealism as it converges with 'local cinematic, political, and intellectual traditions' (Ruberto, Wilson 2014: 4). What remains consistent is the engagement with the everyday and the driving motivation to examine the question 'what is reality?' (Učník 2007: 61).

Latvian filmmaker Laila Pakalnin,a also attempts to engage her audience with reality. Her films, as Liva Pètersone explains, encourage audience members to experience 'real time' and observe 'the most quotidian actions in our lives' (Pètersone 2012). She works in opposition to the 'classical (Hollywood) style' (Rietuma 2012:37), and also in opposition to the dominant artistic conventions of Latvian cinema, such as Andrejs Ekkis' and Aigars Grauba's national 'blockbusters' that attempt to emulate Hollywood conventions. Unlike many contemporary Latvian filmmakers, Pakalninga is not interested in presenting romanticised images of the past, but rather, she uses her films to explore the "subtle and complicated ways' in which the shift from Soviet rule to an independent democratic and capitalist nation has affected and is affecting the everyday man (Vitols 2012: 332).

The stylistics that she employs to examine 'reality' arguably classify her films as part of the global neorealist style. Inga Pērkone contends that her films should be understood as a continuation of what she calls the modernist poetics of the French New Wave and Italian neorealism, particularly in regards to her engagement with loose and open-ended narrative structures (Pērkone 2013: 95). Maruta Vitols states

It is important to highlight that this paper is not endorsing a centre-periphery approach to the examination of alternative film movements across the globe. The Italian neorealists themselves were highly influenced by Grierson, who in turn was influenced by Sergei Eisenstein and Dziga Vertov. However, historically the term 'new wave' was first used for the French New Wave and its progenitor Italian neorealism, which is one reason for using these cinema styles to mark the beginning of the new wave movements. In fact highlighting the similarities between the various new waves across both the East and West hinders the development of a dichotomous framework, suggesting that cultural norms between the regions are not as divergent as some might think. 
that Pakalnina's treatment of landscapes is similar to that of Italian neorealist Michelangelo Antonioni (Vitols 2010: 36), because a celebration of the mundane and an emphasis on the beauty that lies in the quotidian is central to Pakalnina's oeuvre (Vitols 2013: 93). This is highlighted through a similar engagement with 'slice of life' scenes and the use of non-professional actors. Pētersone (2012) also points out Pakalnina's dominant use of static long shots, further aligning her work with Italian neorealist conventions.

Pakalnina's neorealist style developed during her time at the All-Union State Institute of Cinematography (Всесоюзный государственный институт кинематографии, VGIK) in Moscow. The Griersonian poetic documentary tradition was highly valued in the post-Stalin Soviet Union. As Julia Vassilieva states, Grierson re-entered Soviet cinematic culture during Khrushchev's Thaw in the 1960s. After Stalin's death the USSR found itself with a new leader, Nikita Khrushchev, whose cultural policies initially allowed for more artistic innovation and national expression. During Stalin's reign of terror cinema took shape in the form of state-endorsed propaganda, but in this new cultural milieu filmmakers could take more risks and push the boundaries when it came to how life in the Soviet Union could be depicted onscreen. Soviet historians emphasised the 1930s British poetic documentary movement begun by Grierson as a style to emulate, due to its attention to social problems and its poetic treatment of human labour onscreen (Vassilieva 2014: 38). Arguably, the popularisation of Griersonian filmmaking led to an interest in the Italian neorealists and French New Wave who continued the tenets of the British poetic documentary style. The ready access to these film styles informed the development of two key influences on Pakalnina's own style. The first was Andrei Tarkovsky (Auzāne 2012), who was heavily influenced by the Italian neorealists and the French New Wave (Redwood 2010: 21). The second was the Riga School of Poetic Documentary.

The Riga School of Poetic Documen- tary was a movement that formed in the 1960 s during the thaw in the Soviet Union when Griersonian cinema was becoming popular. It should be no surprise that a movement formed in Latvia during this time that emulated the motivations and stylistic techniques of Grierson, and his stylistic successors, the French New Wave and the Italian neorealists. As Vitols points out the Riga School of Poetic Documentary 'provided audiences with films focused on artistic expression ... that encouraged metaphoric readings, frequently suggesting a subversive critique of the totalitarian regime' (Vitols 2012: 328). Pètersone supports Vitols' argument stating that their goal was to film ordinary people with artistic poeticism (Pētersone 2012), similarly to the lauded Griersonian tradition.

The White Bells (Baltie zvani, Latvia, 1961, directed by Ivars Kraulitis), the first film attributed to the Riga School of Poetic Documentary, exemplifies the combination of documentary and fiction that defines this movement. The short film is difficult to categorise. It follows the journey of a young girl who is trying to find her favourite flowers, the white bells. The camera follows her as she weaves through the streets of Riga, overcoming various obstacles to find her flowers. In the end she is successful, although this success seems to be only temporary since, while crossing the street, she drops her flowers, which are then almost flattened by a steamroller. Luckily, someone stops the roller and she runs across to pick up the flowers before the film ends. The narrative of the film is fictional, however, the girl in the film was not a professional actress. (Figure 1) Furthermore, throughout the film the narrative of the girl is interrupted by long shots and extreme long shots of the city of Riga, which are not staged but filmed on location. (Figure 2) The white flowers are a metaphor for the Latvian nation, arguably trying to be reunited with their rightful master, the Latvian people. The sequence with the steamroller is particularly important as it was meant to signify the strength of the Latvian people in the face of the Soviet occupation, sug- 
gesting that their freedom would not be squashed by the Soviet state, but would survive, and they would once again be an independent nation. While the girl's search for the white bells is fictional, the metaphorical narrative was arguably one based in reality.

Pakalnina's films are equally as difficult to categorise and are considered by scholars, such as Vitols (2012) and Pētersone (2012), as being a continuation of the Riga School of Poetic Documentary in the post-communist era. In fact her first feature-length narrative film The Shoe is often discussed by scholars in conjunction with her documentary films, due to her use of location shooting, non-professional actors and an open-ended narrative structure that is formed around the depiction of slice-of-life scenes. While her later fiction films become more definitively fictive, documentary stylistics are still central to her work and are used to 'provide social insight' (Pētersone 2012).

Thus it becomes clear that Pakalnina's cinematic style shares many similarities with neorealism. Her motivation in producing films is to examine the post-Soviet reality of the Latvian nation. To do this she employs techniques similar to those used by the Riga School of Poetic Documentary, the French New Wave and the Italian neorealists among others - all of whom are considered to be part of a global neorealist trend. It is also evident that Pakalnina responds to a very specific socio-political milieu. The neorealist stylistics within her films converges with national traditions and discourses, to create what could ostensibly be called Latvian neorealism. In order to understand how the documentary stylistics of this global style intersects with local concerns, it is first necessary to gain a deeper understanding of the socio-political context to which Pakalnina is responding.

\section{THE TRANSITION FROM SOVIET TO GLOBAL LATVIA}

Pakalnina graduated from the VGIK in 1991; however, she had already begun experimenting with filmmaking in the late 1980s.
Her filmmaking career started in the throes of the social and political upheaval in Latvia, and this is what she 'documents' in her films. Latvia regained its independence from the Soviet Union in 1991 after the unstable and corrupt period of glasnost. This transition from the Soviet era to the new capitalist economy had a profound impact on the filmmaking system in Latvia. It was a period marked by uncertainty with the privatisation of studios and decreased state funding. This led to a great loss of jobs in the industry, resulting in decreased production figures.

This uncertainty was also evident in the social and political spheres in Latvia. At first the collapse of the Soviet Union resulted in what Sigma Ankrava calls a state of euphoria (Ankrava 2004: 26). Many Latvians believed the problems of the Soviet era would just disappear once independence was regained. This state of euphoria quickly turned into bitter disillusionment, as the legacy of the Soviet era continued to create problems for the newly independent nation. The 1990s were marked by instability in the Latvian economy and politics, with widespread corruption as politicians and businessmen exploited the new democratic capitalist system, driven by neoliberal values.

Furthermore, after independence was regained, the Latvian nation lacked a common goal or vision for its future development. The economic and political instability manifested itself on the social level as well, with public opinion divided in regard to what an independent Latvia was and what it meant to be Latvian. The collapse of the Soviet Union brought about the end of the grand Soviet narrative of Socialist Realism, and consequently, the post-Soviet states were thrown into a nascent state of being. The Soviet narrative for each individual nation and the Soviet Union as a whole, which had dictated the understanding of self for over 60 years, dissolved. At the same time it was impossible to return to the homogenous and nationalistic narratives of the nation from the past, such as agrarian nationalism, since Latvia's increasing par- 

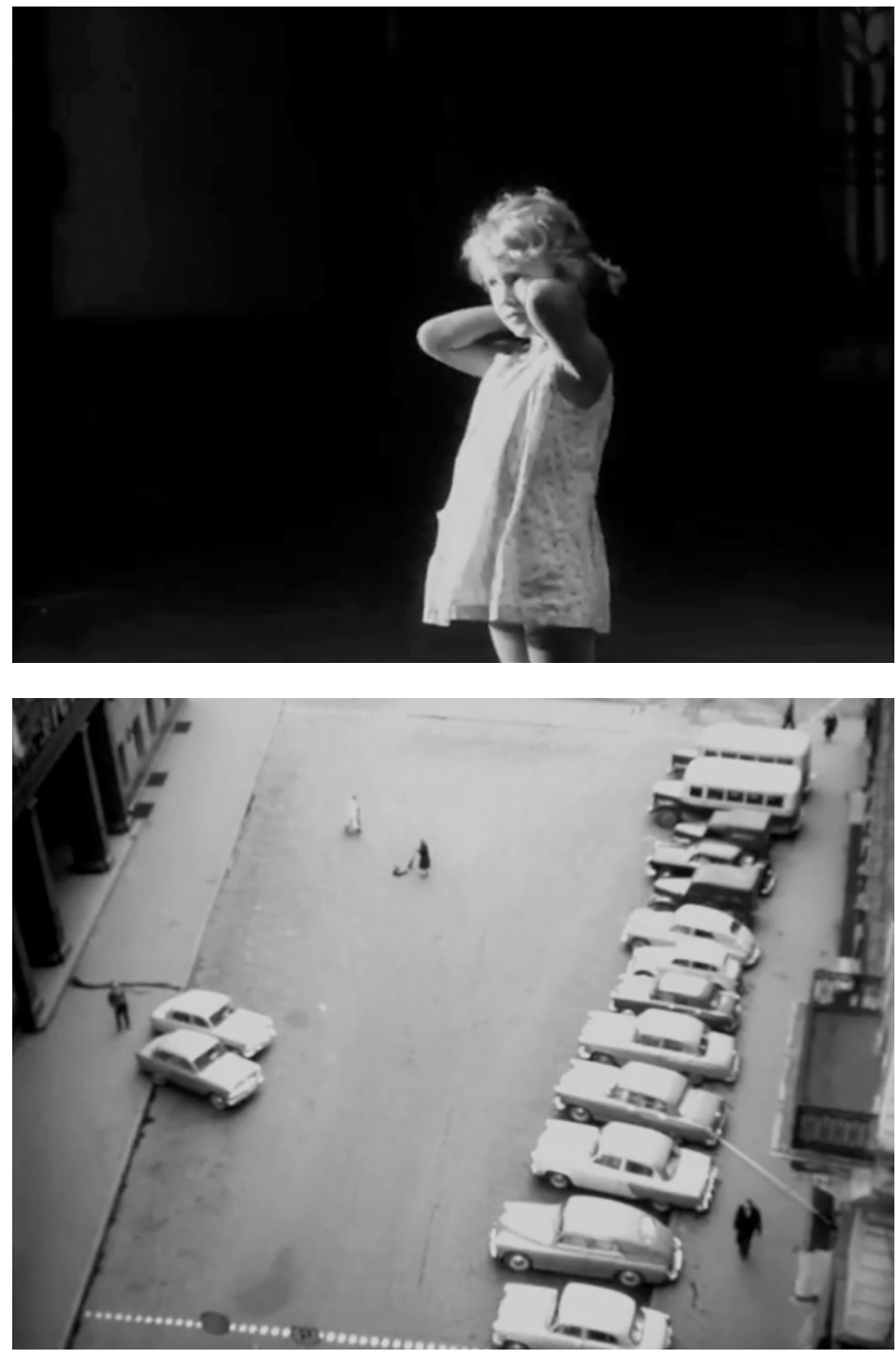

FIGURE 1. The amateur actress searching for the white bells. FIGURE 2. Documentary footage of Riga from The White Bells. 
ticipation in global networks complicated a simplistic ethnocentric understanding of the nation. As Gerard Delanty points out, states become post-sovereign in a globally connected world, complicating a return to a hermetic national identity (Delanty 2009: 119). This period of transition was marked by uncertainty and confusion in regard to the development of a new Latvian identity for the re-independent nation.

This confusion and insecurity led to the development of numerous competing national narratives: the victimhood narrative; agrarian nationalism and liberal internationalism. Ankrava argues that this led to the existence of a postcolonial syndrome in Latvia which is manifested through a profound identity crisis; a crisis that is aggravated by the 'drastic changes in social roles and identities' in Latvia (Ankrava 2004 26-27). Ankrava states that the post-Soviet identity crisis in Latvia is marked by the unsuccessful transition from the Soviet communist system to a free and liberal capitalist market. The people of Latvia are caught in limbo between the demeaning past and the promised democratic and capitalist future. They are in-between, in transit. This transition is evident on the streets of Riga, where Soviet apartment buildings crumble alongside modern new luxury flats, and where advertisements for the latest Gucci handbag or Mercedes car sit amongst the relics of Soviet monuments to the proletariat.

This is the transition that Pakalnina documents in her films. Her earlier work was marked by a critique of the Soviet past (Vitols 2010: 38). However, as the euphoria in the newly sovereign nation started to dissipate, exacerbated by increased global flows of culture and capital, the national identity crisis moved to the fore of public discussion and her films began to contend with the everyday political reality in a transitional Latvia (Vitols 2010: 38).

\section{DOCUMENTING THE TRANSITION}

Pakalnina 'documents' and examines the confusion inherent in the transition from a
Soviet to a democratic and capitalist state. Similarly to the Italian neorealists and the French New Wave, she is not interested in creating films based on a fictional world, which gloss over the social problems and changes occurring in her society, instead she contemplates the present. The neorealist stylistics she employs differs slightly from their manifestation in Italian or French cinema, and is informed by the specific transitional period to which Pakalninga is responding.

\section{Narratives and landscapes: ambulatory cinema}

The cinematic conventions of the new waves developed from a desire to capture the changing nature of society. To achieve this, new wave filmmakers focused on 'documenting' changing landscapes. The loose and open-ended narratives of the films were structured around seemingly random depictions of unrelated landscapes. To retain some narrative coherence, new wave filmmakers often wrote their films around a character's journey through the streets of specific locales. The directors of the French New Wave, for example, 'set their protagonists loose' on the streets of Paris, where they collided and interacted with the 'stuff that together constitutes the miseen-scène of Paris in the 1950s and 1960s' (Tweedie 2013: 88). The directors used characters as vehicles through which they could navigate the city and document the changes occurring in Paris due to the modernisation of post-war France (Tweedie 2013: 91). Tweedie argues that the new wave cinemas are, therefore, 'ambulatory'.

This same 'ambulatory' quality is also visible in Pakalnina's films. Vitols points out that Pakalnina pays little attention to 'conventional patterns of the classic narrative' (Vitols 2010: 37). Landscapes are often the focus of her films. Vitols further asserts that the "life of the spaces [in her films] assumes precedence over the humans that inhabit these landscapes' (Vitols 2010: 36). Pakalnina disregards the demands of narrative, remaining devoted to documentary stylistics that capture moments of change 
in Riga and Latvia. In her earlier work she uses this ambulatory structure to focus on the way the Latvian landscape was changed by the Soviet invasion, which the analysis of The Shoe will demonstrate. In her later work this same ambulatory structure is used to examine the increasing influence of consumer culture on the nation, exemplified by an analysis of Pizzas.

The Shoe is based on a true story told to Pakalnina by her mother. Her mother lived in the military port town of Liepaja on the west coast of Latvia in the 1950s. Every day the military would rake the sand of the beach. If anyone tried to escape from the Soviet Union, or enter it as a spy, their footprints would disrupt the raked sand, and the border guards would be alerted. At that time, Liepaja was one of the most western points of the Soviet Union and one of the most important military bases. One day the patrol found footprints coming out of the water but no footprints entering the sea. The military went on a hunt around the town to find the supposed spy; however, they could not find him or her. This was because a young woman had walked backwards into the water to swim and then carefully followed her footsteps back through the sand to the shore. ${ }^{2}$

The film was inspired by this local tale, and uses it to emphasise the absurdity of the Soviet state's paranoia, as well as to mock the ineptitude of the state's security protocols. Young soldiers are ordered to find the culprit who has left her shoe behind on the beach. In the tradition of postmodern pastiche, the soldiers embark on a Cinderella mission. The film does not have a narrative resolution, nor does the narrative develop in the course of the film.

The loose narrative structure of the film can be understood as a reaction against the restrictions of the Soviet Union. Mark Currie argues that narrative linearity is a way of repressing difference. Soviet propaganda films, which dominated Soviet screens, presented a very particular narrative of the state that aimed to repress 'dissidents' and ensure that people lived their lives according to party rules. Throughout the Soviet era people were brutally oppressed as a result of their ideological differences (Currie 1998: 81). In contemporary Latvian fiction Marcel Cornis-Pope identifies a lack of linear narrative, replaced instead by open-ended and disjunctive texts (Cornis-Pope 2012: 152). He sees this as a reaction to the grand and linear Soviet narrative forced on the Latvian nation during its occupation. These open-ended and disjunctive texts highlight the "unstable nature of self and identity as something in the "making" rather than as something given' (Cornis-Pope 2012: 152). Arguably, this lack of narrative conclusion also reflects the transition Latvia is undergoing in which, to date, the consequences of the past and the direction of the nation's future development are unknown and unclear. It is important to note that this is similar to the Italian neorealists who experimented with narrative structure in opposition to fascist propaganda.

The film's plot is structured simply around the soldiers' journey throughout Liepaja in search of the 'spy'. The camera follows them as they walk through the streets of Liepaja, often at an amble, their path interrupted and changed by interactions with the townspeople and the buildings. The soldiers' interaction with the townsfolk and the landscape is shown to be clumsy and unnatural. The locals are suspicious of the soldiers and their presence disrupts the peace and natural rhythms of the landscape.

The disruptive role of the Soviet soldiers is established in the first moments of the film. The film opens with a long shot of the beach at Liepaja. (Figure 3) The scene is peaceful; the only audible sounds come from the waves lapping up on the shore. The sun is slowly rising over the horizon. This is a typical cinematic moment in Pakalnina's oeuvre. Then suddenly three soldiers and a dog interrupt the peaceful scene, disturbing the pristine sand. (Figure 4) The sonically peaceful atmosphere is shattered by the piercing sound of a whistle. As the scene 

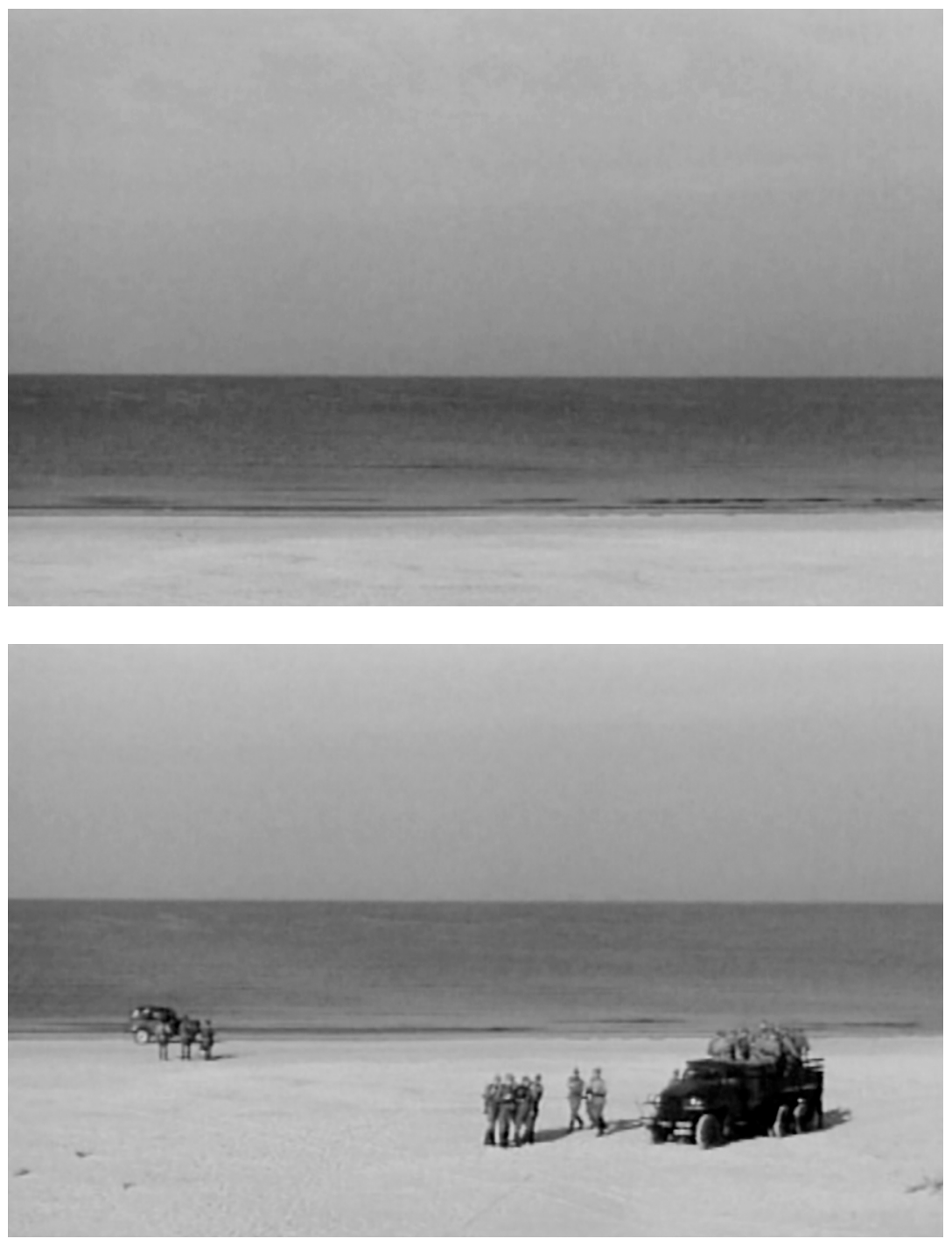

FIGURE 3. The beach in The Shoe before the soldiers arrive.

FIGURE 4. The soldiers disrupt the peace of the space. 

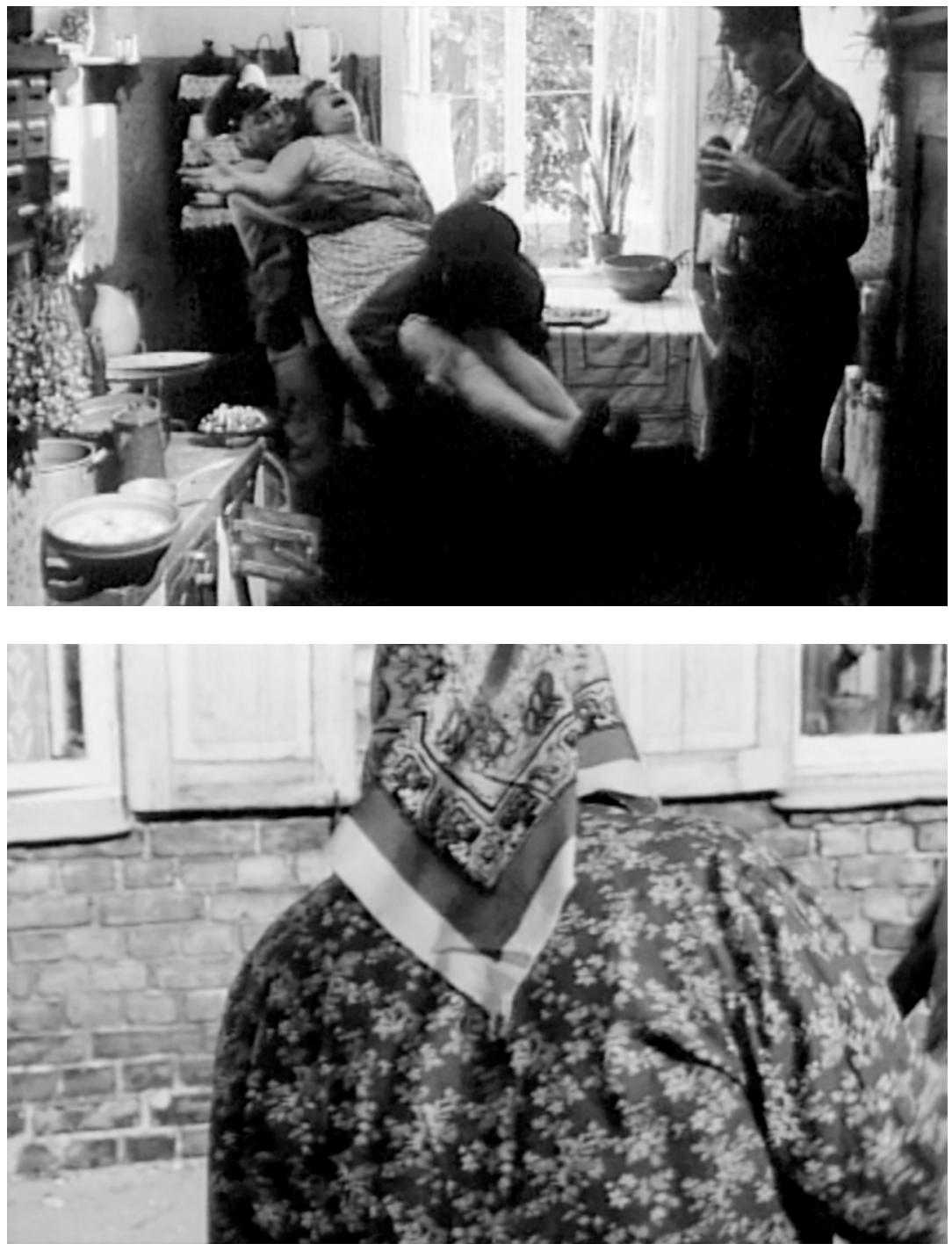

FIGURE 5. The Cinderella story turns into a grotesque nightmare. FIGURE 6. Pakalnina visually represents the rejection of the Soviet past. 
unfolds, more and more army personal and vehicles arrive on the beach, until the landscape Pakalnina presented in the opening moments is almost unrecognisable. Pakalnina is apparently commenting on the forceful and unnatural nature of the Soviet occupation, showing the landscape as pure and unharmed before the Soviet soldiers invaded the space.

Similar disruptive moments are interspersed throughout the film, as the soldiers continue on their journey through Liepaja. Most of the scenes in the film begin with the camera focused on a particular part of the town's landscape; similarly to the opening scene, this landscape is peaceful and quiet. Suddenly the soldiers appear in the frame imposing themselves on the area, changing the landscape visually, sonically and atmospherically. For example, Pakalnina frames a deserted garden at the back of a brick house; again the only audible sounds are those natural to the scene, birds chirping, the wind rustling amongst the long blades of grass. All of a sudden the heavy sounds of army boots interrupt this silence and the figures of the three soldiers sully the brick façade of the house. In yet another scene a cobblestone street is filmed from a high angle. Traditional wooden houses sit on either side of the street. The scene is peaceful, with a young woman leisurely riding her bicycle down the street. All of a sudden an army truck comes roaring past, once again shattering the peaceful atmosphere and changing what Vitols calls 'the life of the spaces' (Vitols 2010: 36).

As the soldiers walk and drive through the various landscapes of Liepaja, they continue to disrupt the daily lives of the town's inhabitants. It is important to highlight that all the townspeople are depicted in 'slice of life' scenes similar to those employed by the Italian neorealists. Pakalnina diverges slightly from the neorealist tradition by constantly interrupting these menial and quotidian activities with the violence of the soldiers, a metaphor for the violence of the Soviet invasion. A woman, for example, is standing at her kitchen sink with her back towards the camera, framed in a long shot.
Suddenly the three soldiers burst into the frame, grabbing the woman and forcing her to try on the shoe they found on the beach. She screams and kicks, afraid of what they want from her. The soldiers hold her down, and force the shoe upon her foot - the story of Cinderella turns into a grotesque night-

\section{mare. (Figure 5)}

Sometimes the soldiers are met with resistance while they disrupt the daily lives of the townspeople. This is most vividly depicted when the soldiers interrupt an old lady sweeping the street outside her house. The soldiers ask if she has seen a strange woman around town. The woman completely ignores the soldiers. Pakalnina powerfully depicts this refusal by directing the attention of the audience to the woman's back. The soldiers remain off screen as they question the woman. The audience is shown a medium close-up of the lower neck and upper back of the woman sweeping the streets. Pakalnina seems to be directing the audience to take note of the refusal, emphasising that this is an important moment. It is as if Pakalnina is bluntly showing the nation 'turning its back' on its Soviet past. (Figure 6)

The Shoe can be seen to document the profound impact that the Soviet invasion and occupation had on Latvia. While the film is fictional and the 'slice of life' scenes are scripted, there are elements of the film that seem to uphold neorealist documentary stylistics. This is true of the landscape scenes, which are shot on location and have not been manipulated by including artificial sets. Furthermore, the people in the 'slice of life' scenes are not professional actors. This is a common characteristic of Pakalnina's films. As Vitols states, 'amateur actors ... move through [her] cinematic spaces ... [in] a quasi-documentary framework' (Vitols 2010: 38). It should be understood that Liepaja represents a microcosm of Latvia in the film. The soldiers are used by Pakalnina as metaphors for the disruptive nature of the Soviet occupation, which not only changed the nature of society but also changed Latvian landscapes. This is facilitated by the ambulatory structure of 

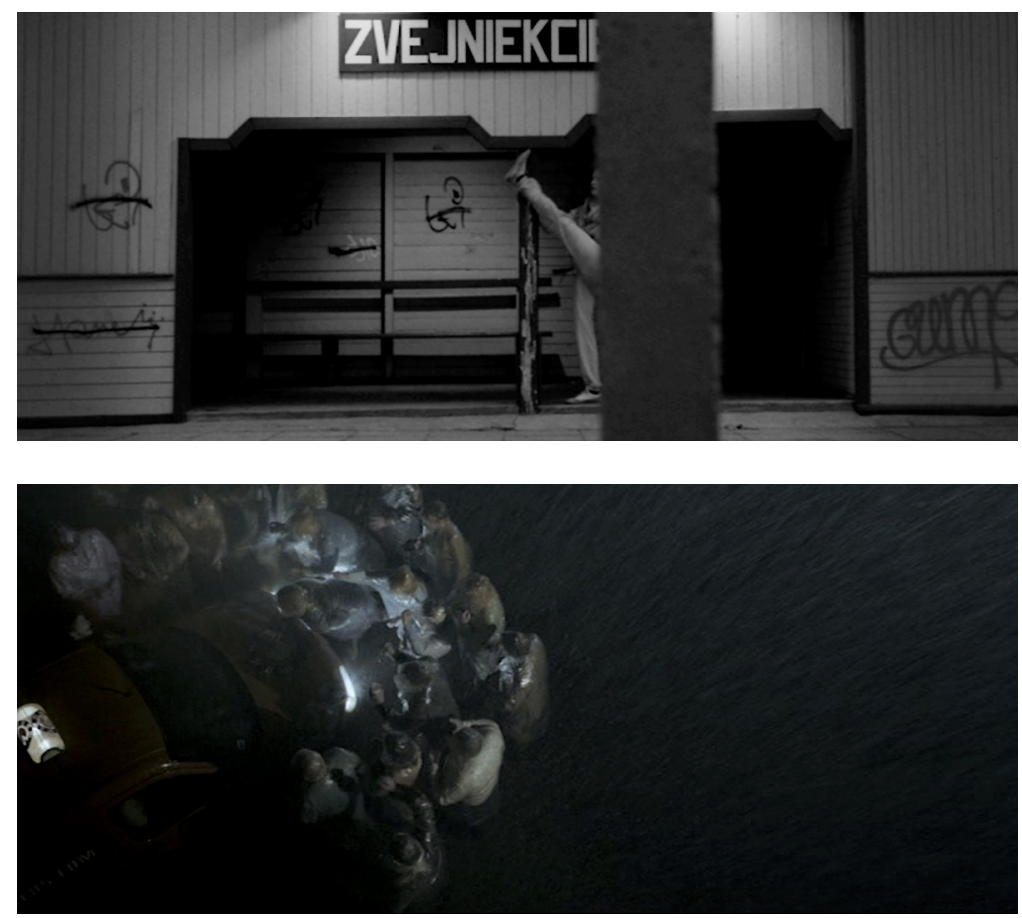

FIGURE 7. A woman stretches at the Zvejniekciems station in a vignette from Pizzas. FIGURE 8 . The wedding party demands ice cream from the pizza boys. 
the film, which follows the journey of the soldiers throughout the city depicting their interaction with the landscapes and people they come across.

In her later films Pakalnina employs the same ambulatory structure to examine the impact that the new capitalist social order has had on the Latvian landscape and the behaviour of the Latvian people. In Pizzas, for example, the structure of the film is based on the journey of two pizza boys who travel through the Latvian countryside and come across various 'slice of life' scenes. Instead of using them to comment on the impact that the Soviet invasion had on the Latvian landscape, this time she uses them to comment on the increasing development of a consumer society in Latvia.

Pizzas, similarly to The Shoe, is based on a true story that Pakalnina came across in a newspaper. Two young men working at a fast-food pizza place get drunk during their shift and decide to steal some money from the cash register. A woman who works with them sees them steal the money. In the absence of the manager, she writes a note documenting what she saw and places it in the safe so that the boys cannot destroy it. The boys desperately try to open the safe but can't, so they steal the safe and drive away. Soon they realise that they are in the pizza company's truck, with the logo plastered all over it. They decide to steal another car and make for the border.

In the film the two boys are from Latvia and they flee to Estonia. Along the way they drift into, or past, various vignettes, such as a wedding party trapped in the rain and desperate for ice cream; a young boy who is lost in the forest whom they mistake for a gnome; and two old ladies that need a light bulb replaced. The film has a very loose narrative thread and these vignettes disrupt the representation of their escape journey and make the film very fragmentary.

For example, seventeen minutes into the film, the boys have already embarked on their journey. A tracking shot follows the pizza van driving down a highway. All of a sudden the camera cuts to a girl stretching at the Zvejniekciems train station. (Figure 7)
A train slowly travels through the station and blocks the girl from view. As the train leaves the station the girl has disappeared. This moment is beyond the 'narrative' of the film, isolated in its own randomness. It is unclear why this moment appears in the film as no context is provided. The interruption of the narrative by the slice of life scenes again demonstrates how Pakalnina re-appropriates this neorealist stylistic technique in order to highlight the specific experience of the Latvian nation. The interruption of the boys' journey by the slice of life vignettes conceivably mirrors the continual occupation of the Latvian nation by greater European powers. The confusion which Pakalnina creates in her audience by inserting these random scenes can be seen to mirror the confusion felt by the Latvian people when their nation was inexplicably occupied by Russia, Poland, Germany etc.

Pizzas is one of Pakalnina's latest films, so she is also commenting on the unrelenting nature of consumer culture, which has become increasingly prominent in Latvia since independence was regained in 1991. Today, the cityscape of Riga is punctuated by advertisements for consumer goods. More and more global fashion companies are opening stores in newly built American-style shopping malls. Their appearance in Riga reflects the consumerdriven culture that is continually developing and becoming increasingly noticeable in Latvia. This drive for consumption and how it has changed the nation is displayed in the vignettes. In one vignette, for example, the boys are stopped by a wedding party. It is night time and rain is falling heavily, but the wedding party crowds around the pizza truck making incessant demands for ice cream. (Figure 8) It is almost as if the advertising on the side of the pizza van has put them into a trance causing them to become animalistic in their desire to get the product that is being sold. The fact that it is a wedding party that is demanding the ice cream is significant, as it arguably contrasts traditional values against those of a capitalist consumer culture. In this scene Pakalnina seems to suggest that the values 
of consumer culture have won.

Similarly to directors from other new waves, Pakalnina structures her films through her characters' journeys. These journeys are not full of adventure, and do not follow a conventional narrative structure, they are ambulatory. This allows her to combine otherwise seemingly unrelated 'slice of life' scenes that 'document' changing landscapes. These slice of life scenes are either interrupted, as in The Shoe, or are interruptive, as in Pizzas. This places a specific national twist on what is arguably a common stylistic in the global neorealist style, leading to the particular manifestation of a neorealism specific to Latvia, built on a narrative of continual occupation.

\section{Decentred subjects}

Another changing element of contemporary Latvian society that Pakalnina aims to 'document' is the confused and conflicted state of the Latvian psyche, which, as argued earlier, is in a state of in-between-ness. The characters in Pakalnina's films cannot be understood, she does not establish a back story for them. In The Shoe, while the motivation for the soldiers' search through the town is presented to the audience, the audience are not allowed to connect with them emotionally. All of Pakalnina's characters are like that; they are characters that do not develop and are almost two-dimensional. This is apparently the result of using characters merely as vehicles with which Pakalnina navigates the changing landscapes of Latvia. Her characters are given a marginal role in the diegetic realm that she creates.

In an interview with Pakalnina, she admitted that she deliberately writes characters that do not develop throughout the film or form a connection with the audience. Rather her characters are part of a mosaic that constitutes her films. They appear and disappear without explanation or development. For Pakalnina characters are like the glue that holds the film's elements together. They are not the most important part of a film for her, just another element of the film's whole that should not necessarily receive more attention than the mise-enscène or the soundscape. For Pakalnina, it is not important that the audience experiences the same emotions as the characters, or empathises with them, but that the audience is drawn into the world of the film through the characters seen onscreen. Atmosphere is of utmost importance to her and her characters are simply there to allow the audience to enter the world of the film and experience the cinematographic atmosphere which has been created. ${ }^{3}$ As Vitols was quoted above, "the life of the spaces themselves assumes precedence over the humans that inhabit these landscapes' (Vitols 2010:36).

Pakalnina's incomplete and fragmentary characters also arguably reflect the ruptured national psyche. It is possible to maintain that her characters provide a commentary on the transition between a socialist state and a sovereign democratic and capitalist nation, and the effect it has had on the Latvian population. This fragmentation is most evident in the protagonists of Pizzas. First of all, only parts of the two actors playing the pizza boys are shown on screen, rarely does the audience see their entire bodies. The opening sequence is a good example. The scene takes place in the pizza parlour. The pizza boys are making absurd pizzas with all sorts of objects - plastic cutlery, nuts and bolts, cardboard and bottle tops. It is obvious that they have been drinking and they decide they need more to drink, but don't have any money to buy more alcohol. This is when the woman catches them stealing money from the till and places a letter in the safe documenting what she has witnessed. This scene, as well as the rest of the film, is filmed so that the characters are almost always shown fragmentarily. (Figure 9)

This sequence exemplifies the fragmentary representation of the characters in the film. If their entire body is depicted, it is usually shot from an extreme angle, or in a position where the protagonists do not dominate the frame. Pakalnina depicts the 

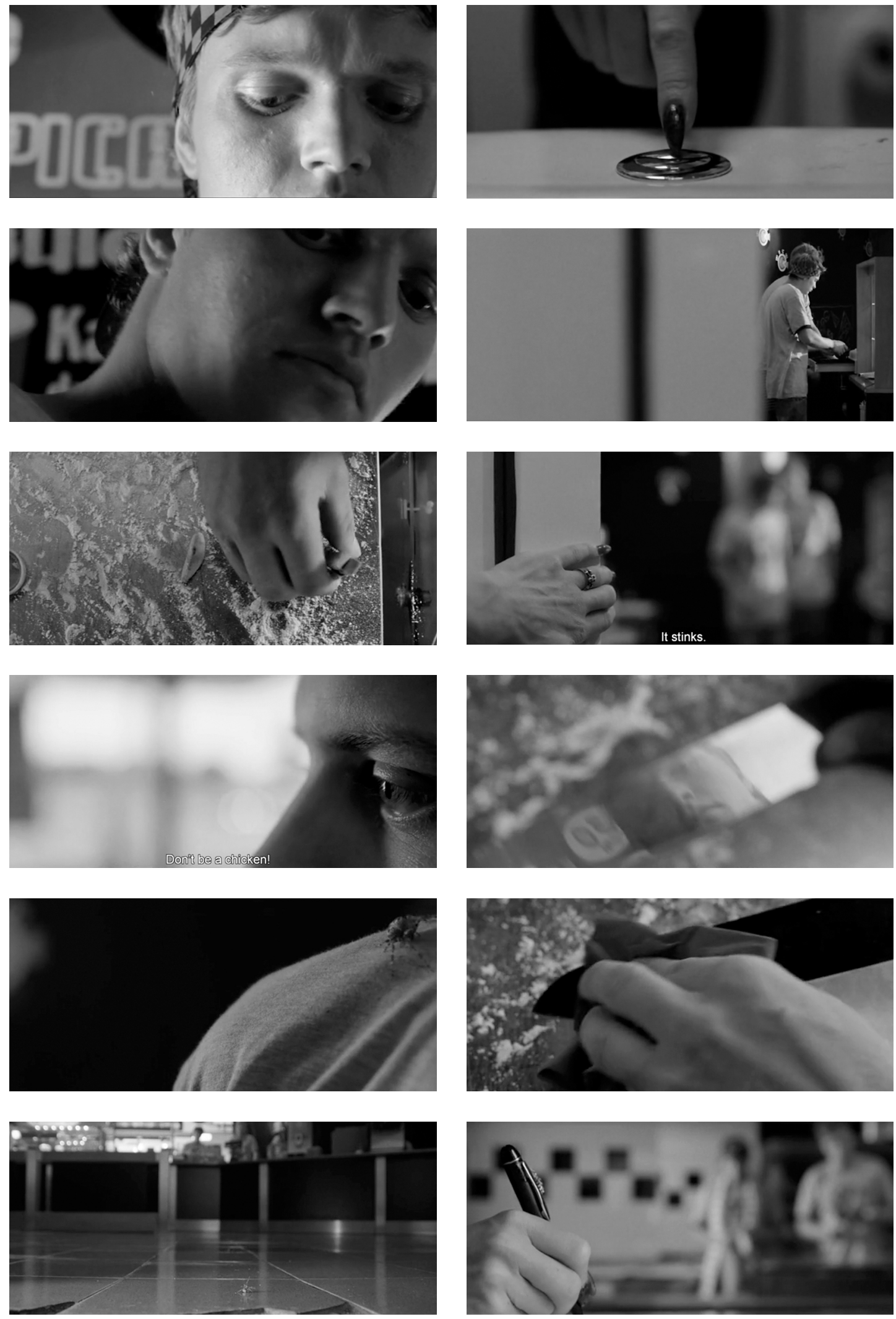

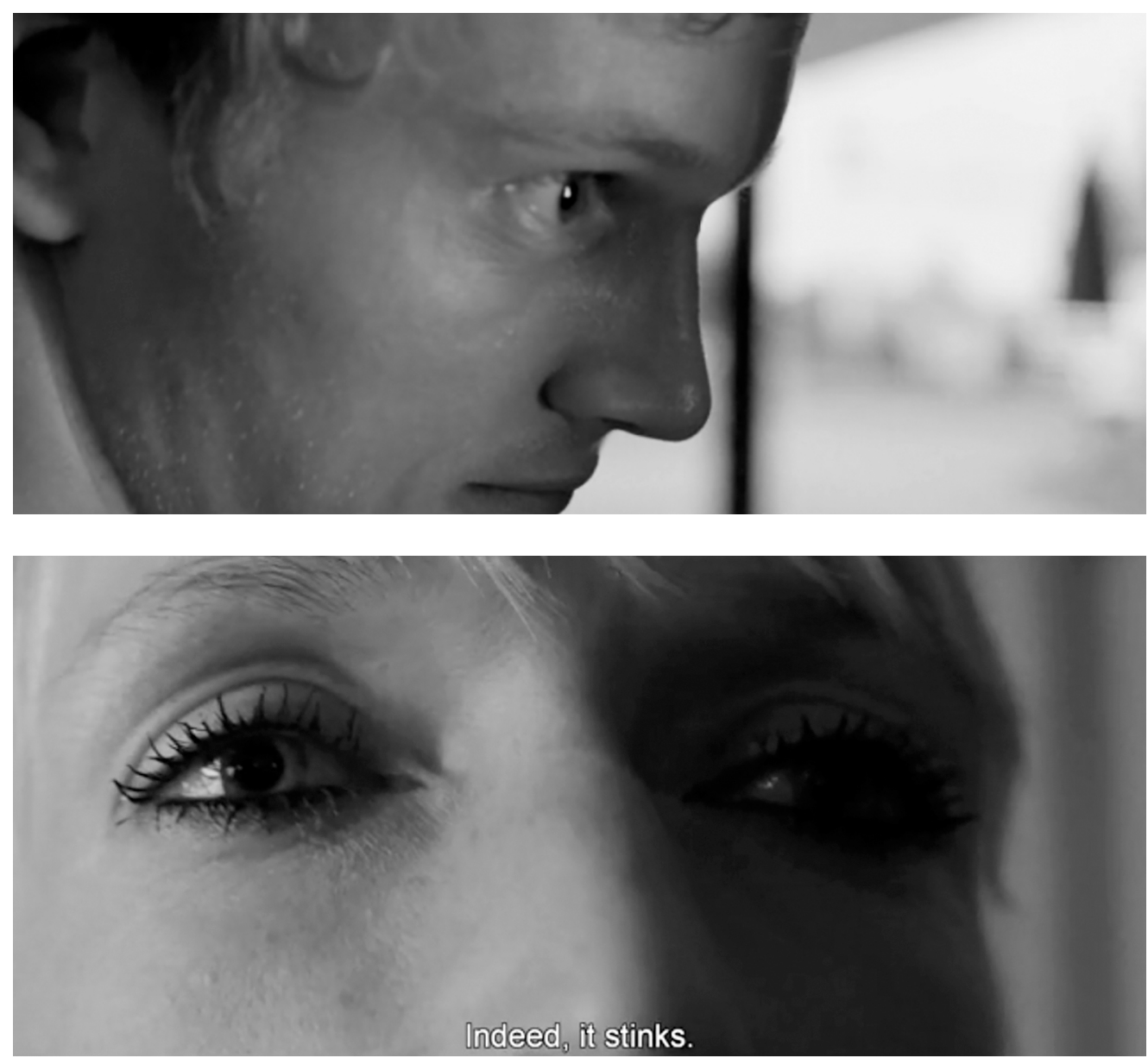

FIGURE 9. This sequence demonstrates the fragmentary representation of Pakalnina's characters. 
characters in a fragmented way, seemingly encouraging the audience to perceive the world in the film as fragmentary as well. The film seems as if it has been patched together, and the intimacy of the shots appears to force the fragmentation into the mind of the audience. This makes it hard to develop a complete picture of the characters, and they also come across as incomplete.

The boys from the pizza parlour are also represented as chaotic and frequently act sporadically and for no reason. One of the last sequences in the film best portrays this randomness. The two boys have finally arrived in Estonia, where they ski down the sand dunes on a beach. Suddenly, one of the boys decides it is time to leave and drives off leaving the other behind. It is another strange scene, in which Pakalnina provides no information about the motivation of the characters, leaving the audience to wonder about the boys' behaviour.

In the scene prior to the one described above, the two boys are sitting in a carwash, scanning the different Estonian radio channels. Abruptly the camera cuts to a medium shot of a beach. The camera focuses on the backs of the two boys, now wearing pink cleaning aprons, with skis and ski poles. They race down the sand dune, one falls down when he gets to the bottom. The camera then cuts to an extreme close-up of an eye, it opens. The camera cuts to a shot of the sky and a hand comes into frame pretending to be an aeroplane. One of the boys is sleeping in a boat that is frozen in the ice. All of a sudden it is winter. The camera cuts to a point-of-view shot from the perspective of the pizza boy: he sees two skis upright in the snow-covered sand. Frantically he starts looking for his friend who is at the other end of the beach. (Figure 10) $\mathrm{He}$ begins to run to music by Latvian rap artist Gacho, musing about his true calling in life. Once the boy finds his friend, his friend tells him he is going back to Latvia. There is no suggestion as to why the boys decided to ski down the sand dune, or an explanation for the sudden leap in time, which the characters do not acknowledge. It is typical of many other scenes in which the boys are shown doing something that make no sense in the context of the narrative, and no reason is provided for their motivation.

Pakalnina's characters are marginalised, as is often the case in other manifestations of neorealist cinema, since filmmakers of various new waves tend to focus on social groups that are not represented in mainstream cinema, both locally and globally. Latvian film in general tends to represent the 'everyday' man. This stems from a negative national discourse in which Latvia is viewed as a nation of victims. In contrast, Pakalnina actively marginalises her characters. They are shown in fragments, often seemingly underdeveloped, whose motivations are hidden from the audience making their actions seem inexplicable and random. In doing so she is commenting on the ruptured national psyche that remains in a transient state after the collapse of the Soviet Union. This divergence from neorealist traditions further highlights how national specificities have led to the re-appropriation of the global neorealist style in Latvia.

\section{CONCLUSION}

Tweedie argues that the numerous new waves that have emerged since World War II re-appropriate the cinematic conventions first made popular by the Italian neorealists. He asserts that they should be viewed as part of a global network, an alternative cinematic globalisation that was created in opposition to the spectacle and fantasy of Hollywood. It is, to borrow Appadurai's term, a 'grassroots' form of globalisation in cinema. The key convention that unifies the various new waves is the deployment of documentary stylistics to capture the changing nature of society during a sociocultural or political moment of upheaval. This is achieved through loosely structured narratives, in which characters are used as vehicles to explore the changing cityscape. There is a particular focus on achieving the greatest possible verisimilitude through the use of non-professional actors and location shooting, even though the films are often classified as fiction. 


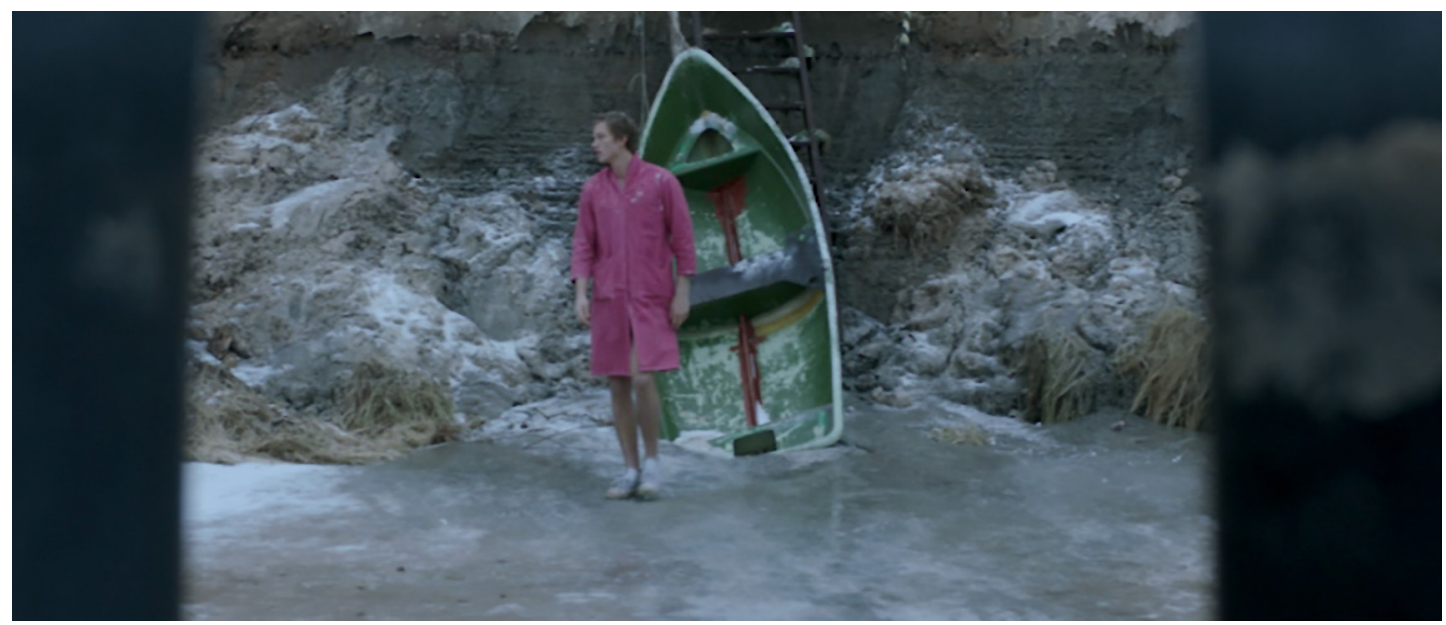

FIGURE 10. One of the pizza boys searches for his friend. 
Inspired by the Riga School of Poetic Documentary, Pakalnina 'documents' the changing nature of Latvian society after the collapse of the Soviet Union in 1991. She does this by employing an ambulatory structure, in which her characters journey aimlessly through different landscapes. Verisimilitude is achieved, similarly to other new wave directors, by shooting on location and hiring non-professional actors. Her earlier films comment on the invasion of Latvia by the Soviets, who in The Shoe are shown to disrupt and violate peaceful landscapes. In her later work, such as Pizzas, she has moved on to examine the increasing presence of consumer goods and consumer culture in Latvia, which is encouraged by increasing global flows. While her films continue the stylistic traditions of global neorealism, she also diverts from convention through the re-appropriation of neorealist techniques to suit an examination of a Latvian reality. In doing so she has created Latvian neorealism. 


\section{REFERENCES}

Ankrava, Sigma 2004. 'The Postcolonial Syndrome and Identity Crisis in Latvia.' - Latvijas Universitätes raksti: Literatūrzinätne, folkloristiska, māksla 666, 24-35. http://www.lu.lv/materiali/apgads/raksti/666.pdf (22 November 2016).

Appadurai, Arjun 2000. 'Grassroots Globalization and the Research Imagination'. - Public Culture 12, 1, 1-19. Auzāne, Ilze 2012. 'Ko gribēšu, to darǐšu'. - Diena, 27 December.

Caminati, Luca 2012. 'The Role of Documentary Film in the Formation of the Neorealist Cinema'. - Saverio Giovacchini, Robert Sklar (eds.), Global Neorealism: The Transnational History of a Film Style. Jackson: University Press of Mississippi, 52-67.

Cornis-Pope, Marcel 2012. 'Local and Global Frames in Recent Eastern European Literatures: Postcommunism, Postmodernism, and Postcoloniality.' - Journal of Postcolonial Writing 48, 2, 143-154.

Currie, Mark 1998. Postmodern Narrative Theory. Hampshire, New York: Palgrave.

Delanty, Gerard 2009. The Cosmopolitan Imagination: The Renewal of Critical Social Theory. Cambridge: Cambridge University Press.

Eades, Caroline 2012. "Another "Cinéma de Papa" for the French New Wave?'. - Saverio Giovacchini, Robert Sklar (eds.), Global Neorealism: The Transnational History of a Film Style. Jackson: University Press of Mississippi, 103-124.

Giovacchini, Saverio; Sklar, Robert 2012. 'Introduction: The Geography and History of Global Neorealism'. Saverio Giovacchini, Robert Sklar (eds.), Global Neorealism: The Transnational History of a Film Style. Jackson: University Press of Mississippi, 3-15.

Hjort, Mette; Petrie, Duncan 2007. The Cinema of Small Nations. Edinburgh: Edinburgh University Press.

Liehm, Mira 1984. Passion and Defiance: Film in Italy from 1942 to the Present. Los Angeles: University of California Press.

Micciché, Lino 2002. 'De Santis e il verisimile'. - Vito Zagarrio (ed.), Non c'e pace tra gli ulivi. Un neorealismo postmoderno. Rome: Scuola Nazionale di Cinema, 7-8. Naficy, Hamid 2012. 'Neorealism Iranian Style.' -

Saverio Giovacchini, Robert Sklar (eds.), Global Neorealism: The Transnational History of a Film Style. Jackson: University Press of Mississippi, 226-239. Neupert, Richard 2007. A History of the French New Wave Cinema. 2nd ed. Madison: University of Wisconsin Press.

Pērkone, Inga 2013. Tu, lielā vakara saule! Esejas par modernismu Latvijas filmäs. Rīga: Neputns.

Pētersone, Liva 2012. 'Latvian Documentary Cinema:

The New Generation'. - KinoKultura, Special Issue 13: Latvian Cinema. http://www.kinokultura.com/ specials/13/petersone.shtml (10 June 2015). Redwood, Thomas 2010. Andrei Tarkovsky's Poetics of Cinema. Newcastle upon Tyne: Cambridge Scholars Publishing.

Rietuma, Dita 2012. 'Intuitīvais trilleris'. - Kino Raksti 4 38, 37-39.

Ruberto, Laura E.; Wilson, Kristi M. 2007. 'Introduction' - Laura E. Ruberto, Kristi M. Wilson (eds.), Italian Neorealism and Global Cinema. Detroit, Michigan: Wayne State University Press, 1-24.

Sadoul, Georges 1966. Histoire du cinema mondial. Paris: Flammarion.

Tweedie, James 2013. The Age of New Waves: Art Cinema and the Staging of Globalization. Oxford: Oxford University Press.

Učník, Lubica 2007. 'Aesthetics or Ethics? Italian Neorealism and the Czechoslovak New Wave Cinema'. Laura E. Ruberto, Kristi M. Wilson (eds.), Italian Neorealism and Global Cinema. Detroit, Michigan: Wayne State University Press, 54-71.
Vassilieva, Julia 2014. John Grierson and Russian Cinema: An Uneasy Dialogue.' - Zoe Druick, Deane Williams (eds.), The Grierson Effect: Tracing Documentary's International Movement. London: Palgrave Macmillan, 29-42.

Vitols, Maruta 2010. 'Alternative Spaces, Alternative Voices: The Art of Laila Pakalnina'. - Renata Šukaityte (ed.), Baltic Cinemas After the 90s: Shifting (Hi)stories and (Id)entities. Vilnius: Vilniaus dailès akademijos leidykla, 33-39.

Vitols, Maruta 2012. 'Investigating the Past, Envisioning the Future: An Exploration of Post-1991 Latvian Documentary.' - Anikó Imre (ed.), A Companion to Eastern European Cinemas. Malden, Oxford: Wiley-Blackwell, 325-343.

Vitols, Maruta 2013. 'Negotiating a New Europe: Laila Pakalnina's The Bus (2004) and Transnational Landscapes.' - Jakub Kazecki, Karen A. Ritzenhoff, Cynthia J. Miller (eds.), Border Visions: Identity and Diaspora in Film. Plymouth: Scarecrow Press, 91-106. 